\title{
TELA'AH PUSTAKA: PEMANFAATAN SMARTPHONE APP PTSD COACH SEBAGAI PROGRAM SELF-MANAGEMENT DALAM MENGATASI GEJALA POST-TRAUMATIC STRESS DISORDER
}

\section{A Review Literature: The Utilization Of PTSD Coach Smartphone App As a Self-Management Program in Overcoming Post-Traumatic Stress Disorder Symptoms}

Putu Dita Wulandari

Departemen Keperawatan Jiwa, STIKES Bina Usada Bali, Badung, Bali, Indonesia Korespondensi : putuwulan68@gmail.com

\begin{abstract}
ABSTRAK
Post-Traumatic Stress Disorder (PTSD) merupakan salah satu kondisi yang ditimbulkan akibat terjadinya bencana. Estimasi prevalensi PTSD bervariasi, sebagian besar berada di kisaran $20-40 \%$ dalam studi bencana dan lebih rendah $3-5 \%$ di beberapa populasi. PTSD yang tidak tertangani menyebabkan tingginya prevalensi depresi, masalah kesehatan dan penurunan kualitas hidup sehingga diagnosis dini dan intervensi tepat waktu penting untuk perbaikan dan pencegahan setiap komplikasi. Penanganan PTSD dapat dilakukan dengan berbagai pendekatan, salah satunya dengan psikoterapi namun faktanya sedikit penderita PTSD menerima perawatan dengan berbagai alasan misalnya masalah logistik, kepercayaan tentang pencarian pengobatan yang tepat, kekhawatiran tentang pemikiran orang lain, dan menganggap bahwa masalah bisa diatasi sendiri. Dengan demikian diperlukan adanya pendekatan alternatif dalam mengatasi permasaahan tersebut. PTSD Coach merupakan salah satu aplikasi smartphone yang berguna sebagai self management dalam pengelolaan gejala PTSD.
\end{abstract}

Kata Kunci : PTSD, PTSD coach, self management, smartphone app

\section{ABSTRACT}

Post-Traumatic Stress Disorder (PTSD) is a condition caused by a disaster. Estimates of the prevalence of PTSD vary, mostly in the 20-40\% range in disaster studies and 3-5\% lower in some populations. Untreated PTSD leads to a high prevalence of depression, health problems and decreased quality of life so early diagnosis and timely intervention are essential for the improvement and prevention of any complications. Handling of PTSD can be done with various approaches, one of which is psychotherapy, but the fact is that few PTSD sufferers receive treatment for various reasons such as logistical problems, beliefs about finding the right treatment, worry about other people's thoughts, and think that problems can be resolved on their own. Thus it is necessary to have an alternative approach in overcoming these problems. PTSD Coach is a smartphone application that is useful as self-management in managing PTSD symptoms.

Keywords: PTSD, PTSD coach, self management, smartphone app 


\section{PENDAHULUAN}

Bencana merupakan salah satu fenomena dunia yang sering kali mendapat sorotan yang intensif. Terjadinya bencana menyisakan berbagai kondisi, salah satunya adalah trauma yang kemudian berkembang menjadi Post-Traumatic Stress Disorder (PTSD). PTSD melibatkan sekelompok gejala kecemasan yang terjadi setelah seseorang telah terkena peristiwa traumatis yang mengakibatkan perasaan ngeri, tidak berdaya dan takut. PTSD biasanya berkembang beberapa bulan setelah peristiwa traumatis (Gordon, Brandish, \& Baldwin, 2016). Penelitian tentang PTSD menjelaskan estimasi prevalensi PTSD bervariasi, sebagian besar berada di kisaran $20-40 \%$ dalam studi bencana dan lebih rendah 3-5\% di beberapa populasi (Bromet et al., 2017).

PTSD yang tidak tertangani menyebabkan tingginya prevalensi depresi, masalah kesehatan dan penurunan kualitas hidup. Selain itu, tejadinya PTSD kronis perlu diwaspadai ketika PTSD tidak tertangani dengan baik. PTSD kronis berlangsung lebih lama dan memiliki prognosis yang lebih buruk sehingga diagnosis dini dan intervensi tepat waktu penting untuk perbaikan dan pencegahan setiap komplikasi (Prakash, Saha, Das, Srivastava, \& Shashikumar, 2016). Penanganan PTSD dapat dilakukan dengan berbagai pendekatan, salah satunya dengan psikoterapi seperti Cognitive Behavior Therapy (CBT) dan Eye Movement Desensitization Reprocessing (EMDR) (Gordon, Brandish, \& Baldwin, 2016). Namun, menurut Wang et al., (2005) dalam Kuhn, Kanuri, Hoffman, Garvert, Ruzek, \& Taylor (2017).

Faktanya sedikit penderita PTSD menerima perawatan kesehatan mental dengan banyak alasan diantaranya masalah logistik, kepercayaan tentang pencarian pengobatan yang tepat, kekhawatiran tentang pemikiran orang lain, dan menganggap bahwa masalah bisa diatasi sendiri (Kuhn et al., 2017). Alasan lainnya menurut Kazdin \& Rabbitt (2013) adalah sedikitnya tenaga kesehatan profesional di daerah-daerah tertentu dalam menangani permasalahan kesehatan mental yang terjadi. Dengan demikian diperlukan adanya pendekatan alternatif dalam mengatasi permasalahan yang ada salah satunya dengan memanfaatkan teknologi yang berkembang saat ini yaitu dengan penggunaan mobile aplication. Penggunaan mobile aplication di bidang perawatan kesehatan mental berkembang sangat pesat dan disajikan sebagai area baru dalam menghasilkan perawatan untuk kesehatan mental (Price et al., 2014). Perkembangan ini berpotensi menjadi pendekatan alternatif dan efisien dalam mengatasi kesehatan mental yang terjadi. PTSD Coach merupakan salah satu aplikasi smartphone yang membantu dalam mengatasi kebutuhan yang tidak terpenuhi dengan menawarkan informasi psychoeducational yang baik dan prilaku kognitif berbasis bukti sehingga mampu dalam pengelolaan gejala PTSD sendiri, sehingga dirasa penting dilakukannya pembahasan penerapan PTSD Coach sebagai self management dalam mengatasi gejala PTSD.

\section{TUJUAN PENULISAN}

Tujuan Penulisan artikel ini adalah melakukan penelusuran pemanfaatan smartphone app PTSD coach sebagai program self-management dalam mengatasi gejala post-traumatic stress disorder.

\section{METODE PENULISAN}

Metode penulisan artikel ini adalah menggunakan metode literature review dengan menelaah berbagai penelitian tentang pemanfaatan smartphone app PTSD coach sebagai program selfmanagement dalam mengatasi gejala posttraumatic stress disorder.

\section{HASIL PENELITIAN}

PTSD coach memiliki efek positif sederhana pada PTSD dan gejala yang terkait namun juga jelas bahwa manfaatnya mungkin tidak cukup kuat untuk dilakukan menjadi satu-satunya langkah perawatan bagi banyak orang dengan PTSD (Kuhn, Kanuri, Hoffman, Garvert, Ruzek, \& Taylor 
2017). Sejalan dengan penelitian yang dilakukan oleh Bahena (2015) hasil umpan balik pelatihan PTSD Coach menunjukkan peserta secara keseluruhan menikmati aplikasi ini, merasa mudah menggunakannya, dan merasa penting untuk memiliki aplikasi PTSD coach. Demikian juga dengan penelitian Kuhn et al (2014) menunjukkan bahwa peserta sangat puas dengan PTSD coach dan menganggapnya cukup membantu dalam mengatasi gejala PTSD yang mereka alami sebelum penderita PTSD mendapat perawatan dari profesional kesehatan.

\section{PEMBAHASAN}

PTSD coach application membantu mengatasi kebutuhan yang tidak terpenuhi dari korban trauma dengan gejala PTSD yang tidak mendapat perawatan kesehatan mental. Meskipun efek PTSD coach dianggap kecil, namun aplikasi bisa menjadi langkah awal yang sangat membantu menuju pemulihan beberapa trauma terutama dirancang untuk meningkatkan kemampuan mengatasi trauma yang berhubungan dengan peristiwa traumatik dan tidak dimaksudkan untuk mengobati gejala PTSD atau mengganti perawatan profesional. PTSD coach memiliki efek positif sederhana pada PTSD dan gejala yang terkait namun juga jelas bahwa manfaatnya mungkin tidak cukup kuat untuk dilakukan menjadi satu-satunya langkah perawatan bagi banyak orang dengan PTSD (Kuhn, Kanuri, Hoffman, Garvert, Ruzek, \& Taylor 2017).

Sejalan dengan penelitian yang dilakukan oleh Bahena (2015) hasil umpan balik pelatihan PTSD Coach menunjukkan peserta secara keseluruhan menikmati aplikasi ini, merasa mudah menggunakannya, dan merasa penting untuk memiliki aplikasi PTSD coach. Demikian juga dengan penelitian Kuhn et al (2014) menunjukkan bahwa peserta sangat puas dengan PTSD coach dan menganggapnya cukup membantu dalam mengatasi gejala PTSD yang mereka alami sebelum penderita PTSD mendapat perawatan dari profesional kesehatan. PTSD coach sebagai intervensi pertama.
Temuan ini mendukung diterimanya penggunaan PTSD coach berpotensi menjadi self-management yang efektif dalam mengatasi PTSD (Miner, Kuhn, Hoffman, Owen, Ruzek, \& Taylor 2016). Temuan tentang PTSD Coach masih berkontribusi pada jumlah yang sedikit namun dalam beberapa literatur yang muncul, aplikasi mobile berpotensi untuk menangani masalah kesehatan mental (Donker et al., 2013).

Dari beberapa penelitian terlihat bahwa PTSD coach bermanfaat dalam mengatasi gejala PTSD. Penderita PTSD bisa mengelola gejala PTSD yang hanya dengan menggunakan item-item yang disedikan dalam PTSD coach. Namun PTSD coach tidak dimaksudkan untuk mengobati gejala PTSD atau mengganti perawatan profesional tetapi hanya untuk meringankan gejala yang timbul akibat trauma. Efek PTSD coach nampak sederhana, namun aplikasi ini menawarkan akses mudah, tanpa biaya, alat psychoeducational dan self-management yang bisa menjangkau sebagian besar korban trauma yang mungkin tidak menerima perawatan.

Penggunaan aplikasi seperti PTSD coach perlu memperhatikan risiko yang melibatkan privasi dan kerahasiaan. Data yang dikumpulkan dari aplikasi bisa diakses oleh individu yang tidak sah melalui pencurian digital atau kehilangan fisik dari telepon dan aplikasi mungkin juga memiliki perlindungan yang kurang memadai dan mungkin tidak sepenuhnya memberikan informasi kepada pengguna tentang tentang cara penggunaanya (Luxton et al., 2011; Prentice \& Dobson, 2014). Keterbatasan lain yang menghabat penggunaan aplikasi termasuk akses pasien untuk menggunakan aplikasi. Beberapa pasien tidak mampu membeli smartphone atau koneksi internet berkecepatan tinggi yang dibutuhkan kemudian untuk mereka yang tinggal di daerah pedesaan mungkin memiliki sinyal terbatas atau tidak ada dan tidasehingga tidak dapat memanfaatkan penggunaannya (Elias, Fogger, McGuinness, \& D'Alessandro 2014). Dari beberapa penelitian terlihat bahwa PTSD coach bermanfaat dalam mengatasi gejala 
PTSD. Penderita PTSD bisa mengelola gejala PTSD yang hanya dengan menggunakan item-item yang disedikan dalam PTSD coach.

\section{KESIMPULAN}

Implikasi

Penggunaan aplikasi PTSD Coach melalui mobile-smartphone bermanfaat dalam mengatasi gejala PTSD. Penderita PTSD bisa mengelola gejala PTSD dengan menggunakan item-item yang disedikan dalam PTSD Coach. Aplikasi ini menawarkan akses mudah, tanpa biaya, alat psychoeducational dan self-management yang bisa menjangkau sebagian besar korban trauma yang mungkin tidak menerima perawatan. Aplikasi ini bisa diterapkan di indonesia, mengingat diindonesia masih banyak kekurangan sumber daya profesional dalam mengatasi PTSD. Sehingga dengan adanya penggunaan aplikasi PTSD Coach diharapkan Penderita yang mengalami PTSD mampu menggunakan aplikasi ini sebagai pertolongan pertama dalam mengatasi gejala dari efek trauma sebelum mendapatkan pertolongan lebih lanjut dari pelayanan kesehatan profesional. Selain itu masih banyak masyarakat indonesia yang enggan mengunjungi fasilitas pelayanan kesehatan mental karena menganggap masalah kesehatan mental merupan masalah yang masih tabu dan masih bisa diatasi sendiri dengan demikian penggunaan aplikasi ini dirasa berguna untuk diterapkan di indonesia. Mengingat aplikasi ini masih jarang digunakan diindonesia dan penggunaan bahasa masih menggunakan bahasa inggris diharapkan pihak- pihak yang berkecimpung dalam bidang kesehatan mampu memperkenalkan aplikasi ini secara luas agar bisa dipergunakan oleh masyarakat umum.

\section{Keterbatasan}

Keterbatasan dalam penulisan artikel ini ada kesulitan mencari sumber dan penelitian terkait tentang pemanfaatan smartphone app PTSD coach sebagai program self-management dalam mengatasi gejala post-traumatic stress disorder.

\section{DAFTAR PUSTAKA}

American Psychiatric Association. (2013). Diagnostic and statistical manual of mental Disorders (5th ed.). Washington, D.C.: American Psychiatric Association.

Bahena, S. (2015). Efficacy of a mobile application among a sample of veterans with symptoms of posttraumatic stress disorder.

Bromet, E. J., Atwoli, L., Kawakami, N., Navarro-Mateu, F., Piotrowski, P.,. . . Kessler, R. C. (2017). Posttraumatic stress disorder associated with natural and human-made disasters in the world mental health surveys. Psychological Medicine, 47(2), 227-241.

Donker, T., Petrie, K., Proudfoot, J., Clarke, J., Birch, M.-R., \& Christensen, H. (2013). Smartphones for smarter delivery of mental health programs: A systematic review. Journal of Medical Internet Research, $15, \mathrm{e} 247$.

Elias, B. L., Fogger, S. A., McGuinness, T. M., \& D'Alessandro, K.,R. (2014). Mobile apps for psychiatric nurses. Journal of Psychosocial Nursing \& Mental Health Services, 52(4), 42-7.

Gordon, R. P., Brandish, E. K., \& Baldwin, D. S. (2016). Anxiety disorders, posttraumatic stress disorder, and obsessive-compulsive disorder. Medicine, 44(11), 664-671.

Healthcare Information and Management Systems Society (HIMSS). (2015). HealthcareInformation and Management Systems Society.

Miner, A., Kuhn, E., Hoffman, J. E., Owen, J. E., Ruzek, J. I., \& Taylor, C. B. (2016). Feasibility, acceptability, and potential efficacy of the PTSD coach app: A pilot randomized controlled trial with community trauma survivors. Psychological Trauma: Theory, Research, Practice, and Policy, 8(3), 384-392.

Price, M., Yuen, E. K., Goetter, E. M., Herbert, J. D., Forman, E. M., Acierno, R., et al. (2014). mHealth: A mechanism to deliver more 
Putu Dita Wulandari: Tela'ah Pustaka: Pemanfaatan Smartphone App PTSD Coach Sebagai Program Self-Management dalam Mengatasi Gejala Post-Traumatic Stress Disorder

accessible, more effective mental health care. Clinical Psychology \& Psychotherapy, 21(5), 427436.

Prakash, J., Saha, A., Das, R. C., Srivastava, K., \& Shashikumar, R. (2016). Post traumatic stress disorder. Medical Journal Armed Forces India, 72(2), 189-191.

Kazdin, A. E., \& Rabbitt, S. M. (2013). Novel models for delivering mental health services and reducing the burdens of mental illness. Clinical Psychological Science, 1, 170 -191.

Kuhn, E., Kanuri, N., Hoffman, J. E., Garvert, D. W., Ruzek, J. I., \& Taylor, C. B. (2017). A randomized controlled trial of a smartphone app for posttraumatic stress disorder symptoms. Journal of Consulting and Clinical Psychology, 85(3), 267273.

Kuhn, E., Greene, C., Hoffman, J., Nguyen, T., Wald, L., Schmidt, J., ... \& Ruzek, J. (2014). Preliminary evaluation of PTSD Coach, a smartphone app for post-traumatic stress symptoms. Military Medicine, 179(1), 12-18. 